Mhanna, A. M., Douay, W. F., Rajab, M (2021): Flowering behavior of French olive cultivar Picholine under Syrian coast conditions. Agriculture and Forestry, 67 (1): 139-149

DOI: 10.17707/AgricultForest.67.1.12

Mohammad A. MHANNA ${ }^{1}$,

Faisal W. DOUAY ${ }^{2}$, Mazen RAJAB ${ }^{1}$

\title{
FLOWERING BEHAVIOR OF FRENCH OLIVE CULTIVAR 'PICHOLINE' UNDER SYRIAN COAST CONDITIONS
}

\begin{abstract}
SUMMARY
The study was conducted in Bouka center for research and plant production, Syria, in order to study flowering behavior of French olive cultivar 'Picholine'. Average number of flowers per inflorescence, pistil abortion (\%) and fertile inflorescence (\%) were studied in three positions of flowering shoots (apical, middle and basal position) in 2018 and 2019 seasons. Chilling units, flowering dates and growing degree days were also estimated in 2017, 2018 and 2019 seasons. Results showed that the number of flowers per inflorescence was not changing between seasons, but it was influenced by inflorescence position on the shoot. Pistil abortion was significantly lower in the basal position compared to inflorescences located in the apical and middle position of the shoots. Ratio between the number of flowers per inflorescence and the number of flowers with aborted pistils differed depending on inflorescence position on the shoot and season. In total, the number of flowers per inflorescence was responsible for $11 \%$ of the variation in pistil abortion in 2018, and 37\% in 2019 season. Chilling units differed considerably among seasons, 2018 had the lowest chilling units, while 2017 had the highest. 'Picholine' flowered regularly even under low chilling conditions showing to have lower chilling requirements and consequently could adapt well to areas with relatively warm winters. This could be an advantage under global climatic change.
\end{abstract}

Keywords: pistil abortion, chilling, growing degree days, Picholine, inflorescence position.

\section{INTRODUCTION}

Olive (Olea europaea L.) is an iconic tree of the Mediterranean. Olive flowers on shoots from previous year growth in inflorescence or sometimes called "panicle" or "cluster", where the quantity and quality of the flowers could determine the commercial yield (Rapoport et al., 2012).

\footnotetext{
${ }^{1}$ Mohammad A. Mhanna (corresponding author: agrihort@yahoo.com), Mazen Rajab, General Commission for Scientific Agricultural Research, Latakia, SYRIA;

${ }^{2}$ Faisal W. Douay, Department of horticulture, faculty of agriculture, Tishreen University, Latakia, SYRIA;

Notes: The authors declare that they have no conflicts of interest. Authorship Form signed online. 
Olive is andromonoecious crop, i.e. having both hermaphrodite and staminate flowers on the same plant. Staminate flowers occur as a result of different level of pistil abortion, a phenomenon differs considerably between olive cultivars and could influence fruit set and consequently tree yield (Rosati et al., 2012; Selak et al., 2019).

Flowering characteristics could affect fruit characteristics and yield, because yield depends on fruit number and weigh, two parameters influenced by flower quality and quantity (Rosati et al., 2012). Moreno-Alias et al. (2013) mentioned that flower quality has significant influence on yield, so it's an important parameter in olive breeding programs. The same researchers reported that the new olive cultivar 'Sikitita' which resulted from the hybridization /'Picual' $(+9) \times$ 'Arbequina' $\left(0^{\top}\right) /$ had the same number of flowers per inflorescence of the father and intimidate between the two fathers in hermaphrodite flowers ratios.

Studies reported many factors which could affect pistil abortion such as genetic factor, Alagna et al. (2016) reported many genes involved in pistil abortion of olive such as BAM 1, Inv-cw, Inv-V and GBSSI which involve in starch and sucrose metabolism and NLP1, SPDS and $A D C$ which involve in polyamines biosynthesis. In addition, environmental conditions like drought, mineral deficiency and previous year yield could affect flower gender in olive (Rapoport et al., 2012; Rosati et al., 2012; Beya-Marshall and Fichet, 2017).

Garcia-Mozo et al. (2009) mentioned that phenological data is an important and sensitive tool in evaluating the adaptability of plants in local environments and how those plants respond to climate change. Olive cultivars reported to require sufficient level of chilling (below 7.2 $\mathrm{C}$ ) for bud differentiation and olives growing under stable temperature above $15.5^{\circ} \mathrm{C}$ do not flower at all (Hartmann and Porlinglis, 1957).

Olive cultivars differ in chilling requirements between low chilling requirements like 'Koroneiki' and high like 'Sevillano' (Aybar et al., 2015; Malik and Bradford, 2006). Koubouris et al. (2019) reported a decrease in the number of flowers/inflorescences in Greek olive cultivars 'Koroneiki' and 'Mastoides' resulted from low chilling, while no effect was found on inflorescence length or width. Any way the threshold used in calculating chilling requirements differed among authors, where some used $7.2^{\circ} \mathrm{C}$ (Hartmann and Porlinglis, 1957; Zouari et al. 2017), while others used $9,10,12.5,15$ and/ or $16^{\circ} \mathrm{C}$ (Alcalá and Barranco, 1992; Haberman et al., 2017; Selak et al., 2018; Koubouris et al., 2019). Other studies reported different thresholds depending on latitude, so thresholds are lower in olive orchards located at higher latitudes (Aguilera et al., 2014).

In this study, flowering behavior of French olive 'Picholine' was studied; also chilling and heat requirements provided by study area were calculated in order to evaluate the response of this cultivar to different chilling units throughout three concessive years characterized by different climatic conditions. 


\section{MATERIAL AND METHODS \\ Study location and Plant material:}

The study was conducted in Bouka center for research and plant production, Latakia province, Syria, $40 \mathrm{~m}$ above sea level. A 30 years old trees of French olive cultivar 'Picholine' was studied.

\section{Methods:}

In 2018 and 2019, four uniform sized trees of olive cultivar 'Picholine' with high level of flowering were chosen for the study (category 5) according to (Ramirez-Santa Pau et al., 2002). a sample of 75 inflorescences was taken from random one-year old shoots distributed around the canopy at white bud stage in each tree as follows: 25 inflorescence from the apical part of the shoot, 25 inflorescence from the middle part of the shoot and 25 from basal part of the shoot. For each part of the shoot the following parameters were evaluated:

Average number of flowers per inflorescence $=$ total number of flowers in the sample/ number of inflorescences.

Pistil abortion $(\%)=($ number of flowers with non-functional pistils/ total number of flowers) $\times 100$.

Fertile inflorescences $(\%)=$ (number of inflorescences containing at least one hermaphrodite flower/ total number of inflorescences) $\times 100$ (Sanchez-Estrada and Cuevas, 2020).

The start of flowering (stage 61), and the end of flowering (stage 69) was estimated according to (Sanz-Cortés et al. 2002). Maximum and minimum daily air temperatures for three years $(2017,2018$ and 2019) were obtained from meteorological station located 3-4 km from the study orchard. Flowering dates (FD) were calculated as the number of days from January 1 until the start of flowering in each year.

Chilling accumulation (CU) for each study season was calculated as follows:

$$
\mathrm{CU}=((\mathrm{T}-\mathrm{m}) /(\mathrm{M}-\mathrm{m})) \times 24,
$$

where $\mathrm{T}$ is the threshold air temperature $\left(7.2\right.$ and $12.5^{\circ} \mathrm{C}$ were used), $\mathrm{M}$ is the daily maximum air temperature, $\mathrm{m}$ is the daily minimum air temperature. The chilling period started in the first day in autumn when the mean daily air temperature dropped below the threshold temperature followed by subsequent days with air temperature below the threshold (Aron and Gat, 1991; Zouari et al., 2017; Selak et al., 2018).

Heat accumulation expressed as growing degree days (GDD) starts the day after chilling period stopped and continued until the start of flowering. GDD was estimated as follows:

$$
\mathrm{GDD}^{\circ}=\{(\mathrm{Tm}+\mathrm{TM}) / 2\}-\mathrm{T} 0
$$

$\mathrm{Tm}$ is the daily minimum air temperature; TM is the daily maximum air temperature; $\mathrm{T} 0$ the threshold temperature. 


\section{Experimental design and statistical analysis:}

Two-way randomized blocks design was used with four replications. Data were arcsine transferred when necessary and subjected to ANOVA. Means were separated using Duncan multiple range test $(P \leq 0.05)$. CoStat version 6.400 Copyright(c) 1998- 2008 CoHort software, CA, USA was used for statistical analysis.

\section{RESULTS AND DISCUSSION \\ Number of flowers per inflorescence}

Average data of the number of flowers per inflorescence are presented in Table 1. The data shows little influence of the position on the branch on inflorescence. The number of flowers per inflorescence was not changing significantly between apical and middle position on the flowering shoots, whereas different behavior was observed for the basal position. In 2018 season, basal position had significantly the highest number of flowers per inflorescence, while in 2019 season the opposite situation was observed. Anyway, the average of the two years data showed that the number of flowers per inflorescence was decreasing from the apical to the basal position of the shoot by almost $11 \%$.

Table 1. Number of flowers per inflorescence of olive cultivar 'Picholine' depends on season and inflorescence position on the shoots

\begin{tabular}{|c|c|c|c|}
\hline Inflorescence position on the & \multicolumn{2}{|c|}{ Season } & \multirow{2}{*}{ Mean seasons } \\
\cline { 2 - 3 } branch & 2018 & 2019 & \\
\hline Apical & $15.81 \mathrm{ab}$ & $17.23 \mathrm{a}$ & $16.52 \mathrm{a}$ \\
\hline Middle & $14.69 \mathrm{~b}$ & $16.97 \mathrm{a}$ & $15.83 \mathrm{a}$ \\
\hline Basal & $17.17 \mathrm{a}$ & $12.30 \mathrm{~b}$ & $14.74 \mathrm{a}$ \\
\hline Mean positions & 15.89 & 15.5 & 15.70 \\
\hline P-value (seasons) & \multicolumn{3}{|c}{0.555} \\
\hline P-value (positions) & \multicolumn{3}{|c}{0.117} \\
\hline
\end{tabular}

Means followed by different letters within columns indicate significant differences using Duncan test $(\mathrm{P} \leq 0.05)$.

Regardless of inflorescence position, season had no-effect on the number of flowers per inflorescence because both seasons gave almost the same number of flowers per inflorescence (15.89 and 15.5 flower/inflorescence in 2018 and 2019 , respectively). The fluctuating results between apical and basal positions could refer to different nutritional and climatic conditions by the time of bud burst and inflorescence axil growing in the study seasons. Ghrisi et al. (1999) studied 'Picholine' at the Menara station in Morocco and they found that this cultivar had high average number of flowers per inflorescence compared with 'Picholine Marocaine', 'Souri', 'Manzanilla' and 'Arbequina'; they also reported no significant differences in number of flowers per inflorescence between the two years of their study. Mhanna et al. (2020) also reported no significance differences in the number of flowers per inflorescence among seasons for the autochthonous Syrian olive cultivar 'Dermlali' in the same location. 


\section{Pistil abortion and fertile inflorescence}

Quality of the flowers in two years period is presented in Table 2. Pistil abortion was significantly influenced by inflorescence position on the shoot in both seasons. Although no significant differences in pistil abortion were found between apical and middle position of the shoot, pistil abortion was higher in these two positions compared to the basal position. The pistil abortion increased from the base to the top of the shoot where pistil abortion reached the maximum level (63.98\% as mean of the 2018 and 2019 seasons). This could refer to better nutritional position of the basal buds and inflorescence compared to apical positions where more competition for metabolites between flowers and vegetative growth could be found; also hormone distribution in the shoots could differ between apical and basal position and this could affect sex expression (Gupta and Chakrabarty, 2013). However, mentioned explanations need further study. Mhanna et al. (2019a) found no significant differences in pistil abortion between the apical, middle and the basal positions of inflorescence on the flowering shoots of Italian olive cultivar 'Coratina', this could refer to low pistil abortion ratio of this cultivar compared to 'Picholine', a phenomenon seemed to be cultivar dependent.

Table 2. Influence of season and inflorescence position on the shoots on pistil abortion (\%) of olive cultivar 'Picholine'.

\begin{tabular}{|c|c|c|c|}
\hline \multirow{2}{*}{ Position/season } & \multicolumn{2}{|c|}{ Season } & \multirow{2}{*}{ Mean seasons } \\
\cline { 2 - 3 } & 2018 & 2019 & \\
\hline Apical & $50.24 \mathrm{a}$ & $77.72 \mathrm{a}$ & $63.98 \mathrm{a}$ \\
\hline Middle & $50.12 \mathrm{a}$ & $66.30 \mathrm{a}$ & $58.21 \mathrm{a}$ \\
\hline Basal & $28.47 \mathrm{~b}$ & $45.15 \mathrm{~b}$ & $36.81 \mathrm{~b}$ \\
\hline Mean positions & 42.94 & 63.06 & 53.00 \\
\hline P-value (seasons) & \multicolumn{3}{|c}{0.000} \\
\hline P-value (positions) & \multicolumn{3}{|c}{} \\
\hline
\end{tabular}

Means followed by different letters within columns indicate significant differences using Duncan test $(\mathrm{P} \leq 0.05)$.

Season also affected pistil abortion significantly, from $42.94 \%$ in 2018 to $63.06 \%$ in 2019.

Multiple comparisons showed significant interaction between season and inflorescence position on the shoot. Apical position of 2019 season had significantly the highest pistil abortion ratio $(77.72 \%)$, while basal position in 2018 season had the lowest $(28.47 \%)$.

Regarding the presence of the fertile inflorescence (Table 3), it was not changing significantly when analyzing each season alone, but factorial analysis showed that fertile inflorescence $(\%)$ on the basal position was superior to middle and apical position. The season also affected this parameter, in 2018 season there was significantly the highest fertile inflorescence (96.44\%).

Significant interaction between season and position was found. The highest fertile inflorescence (\%) was on the middle position of 2018 season (98.67), 
while apical position of 2019 season had significantly the lowest fertile inflorescence $(68 \%)$.

Table 3. Influence of season and inflorescence position on the shoots on fertile inflorescence (\%) of olive cultivar 'Picholine'.

\begin{tabular}{|c|c|c|c|}
\hline \multirow{2}{*}{ position/season } & \multicolumn{2}{|c|}{ Season } & \multirow{2}{*}{ Mean seasons } \\
\cline { 2 - 3 } & 2018 & 2019 & \\
\hline Apical & $93.33 \mathrm{a}$ & $68.00 \mathrm{a}$ & $80.67 \mathrm{~b}$ \\
\hline Middle & $98.67 \mathrm{a}$ & $88.00 \mathrm{a}$ & $93.34 \mathrm{a}$ \\
\hline basal & $97.33 \mathrm{a}$ & $86.77 \mathrm{a}$ & $92.05 \mathrm{a}$ \\
\hline Mean positions & 96.44 & 80.92 & 88.69 \\
\hline P-value (seasons) & \multicolumn{3}{|c}{0.001} \\
\hline P-value (positions) & \multicolumn{3}{|c}{019} \\
\hline
\end{tabular}

Figure (1) shows the relationship between the number of flowers per inflorescence and the number of flowers with aborted pistils in each shoot position. The apical part of the shoot (figure 1, A) showed significant correlation between the number of flowers per inflorescence and the number of flowers with aborted pistil $\left(r=0.29 *, \mathrm{R}^{2}=0.087\right)$ in 2018. This correlation increased in 2019 $\left(\mathrm{r}=0.63^{* * *}, \mathrm{R}^{2}=0.39\right)$ (figure $\left.1, \mathrm{~A}^{\prime}\right)$. In middle part (figure $\left.1, \mathrm{~B}\right)$, low and insignificant correlation between number of flowers per inflorescence and the number of flowers with aborted pistil was found in $2018\left(\mathrm{r}=0.08^{\mathrm{ns}}, \mathrm{R}^{2}=0.006\right)$, while in 2019 , this relation was significant $\left(r=0.4, R^{2}=0.16\right)$ (figure $\left.1, B^{\prime}\right)$. In basal part of the shoot (figure $1, \mathrm{C}, \mathrm{C}^{\prime}$ ), the correlation was significant in both seasons ( $\mathrm{r}=0.32^{* *}, \mathrm{R}^{2}=0.10 ; \mathrm{r}=0.29^{*}, \mathrm{R}^{2}=0.08$, respectively).

Correlation results indicated that the number of flowers per inflorescence influenced the pistil abortion, but its effect differed between seasons and inflorescence position on the shoot, maximal in the apical part, and minimal in the middle part of the flowering shoot. This indicates that in the apical position stronger competition between flowers could be found.

When merging all data together, correlation between the number of flowers per inflorescence and the number of flowers with aborted pistils was significant $\left(\mathrm{r}=0.34^{* * *}, \mathrm{R}^{2}=0.11\right)$ in 2018 season (figure $\left.1, \mathrm{D}\right)$, and $\left(\mathrm{r}=0.61^{* * *}\right.$, $\mathrm{R}^{2}=0.37$ ) in 2019 season (figure 1, $\mathrm{D}^{\prime}$ ). Depending on coefficient of determination, the number of flowers per inflorescence was responsible for $11 \%$ of the variation in pistil abortion in 2018, and 37\% in 2019 season, while the rest of variation could refer to other factors such as moisture, nutrients, etc.

\section{Chilling accumulation, Flowering dates and heat requirements:}

The start of flowering, flowering period extension, flower quality and quantity, fruit set, fruit development and ripening, all influenced by environmental conditions especially temperature and moisture (Bonofiglio et al., 2008; Rapoport et al., 2012). Figure 2 shows that 2018 season was warmer than 2017 and 2019 seasons. Table 4 shows that flowering date of 'Picholine' occurred on 109th day in 2017 season, and on 101st day in 2018 season what was earlier compared to 2017 but delayed for 15 days in 2019 season. 


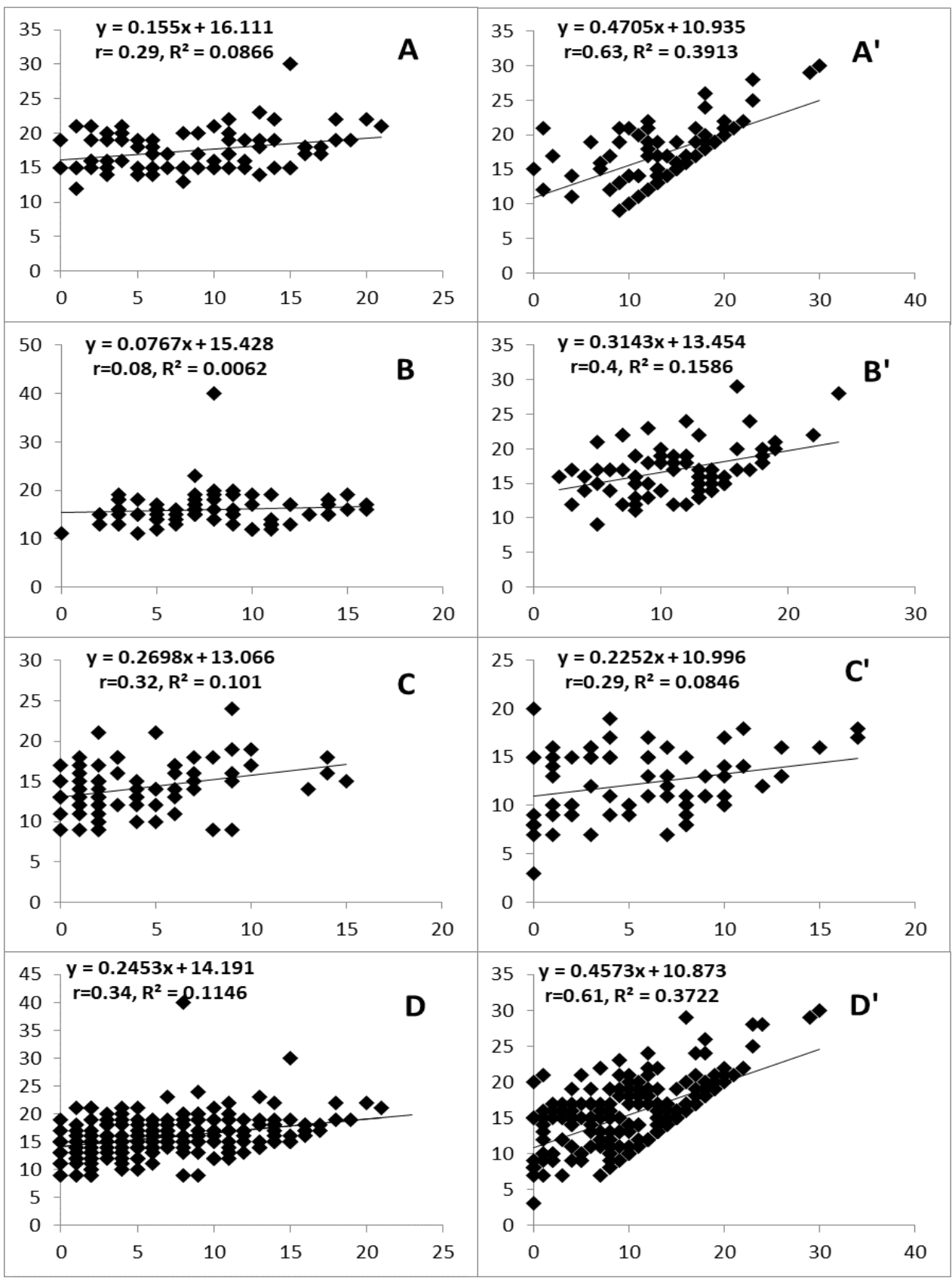

Figure 1. Linear relationship between the number of flowers per inflorescence (Y axis) and the number of flowers with aborted pistils (X axis) in different positions of inflorescence on the shoot: A: apical part, B: middle part, C: Basal part, in 2018 season $\left(\mathrm{A}^{\prime}, \mathrm{B}^{\prime}, \mathrm{C}^{\prime}\right)$ in 2019 season. 
Chilling units varied widely depending on the threshold used and seasons. When using the traditional threshold temperature $\left(7.2^{\circ} \mathrm{C}\right)$, chilling units were low in general reaching 51.2 units in 2017, and only $16.6 \mathrm{u}$ in 2019 , but was null ( 0 unit) in 2018 season. When $12.5^{\circ} \mathrm{C}$ was used as threshold, chilling units were $1284.6 \mathrm{u}$ in 2017, $326.4 \mathrm{u}$ in 2018 and $612 \mathrm{u}$ in 2019. In general, 2017 season had the highest chilling units, while 2018 had the lowest.

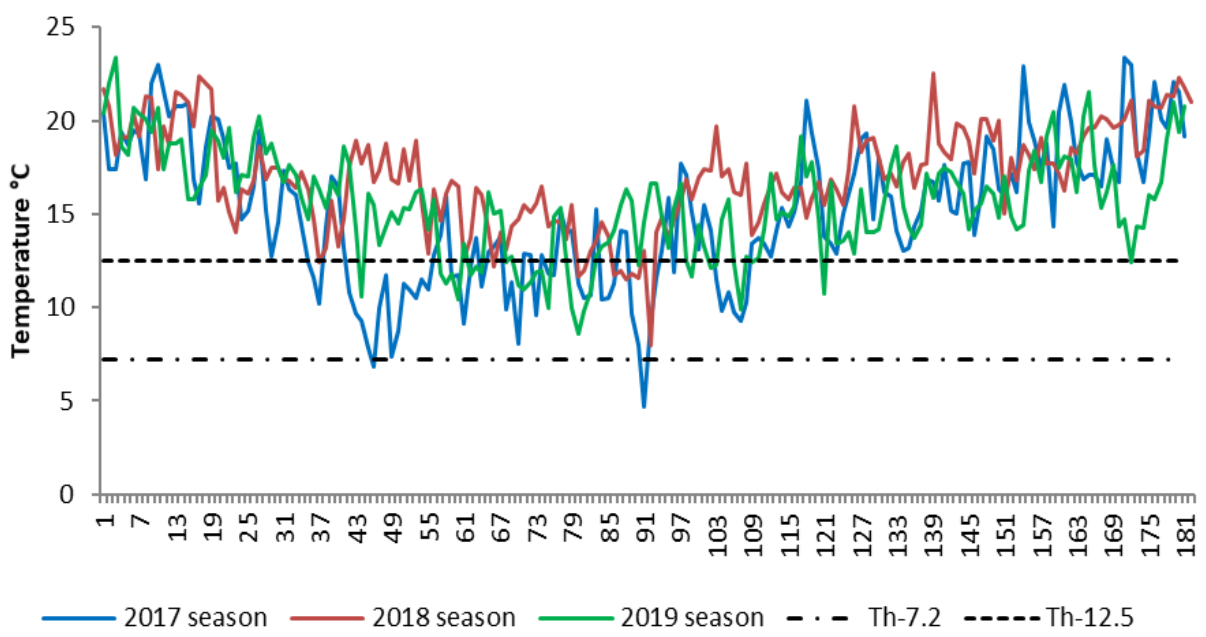

Figure 2. Mean air temperature $\left({ }^{\circ} \mathrm{C}\right)$ in Bouka, Latakia for the period from $1^{\text {st }}$ November to $30^{\text {th }}$ April for 2017, 2018 and 2019 seasons.

Growing degree days (GDD) also differed considerably; it reached the maximum level in 2018 season (1197.4 and 316.2) depending on the threshold used, while 2019 season had the lowest GDD. No clear relationship between FD, CU and GDD was found. Zouari et al., (2017) studied chilling and heat requirements in Sfax (Tunisia) and they found inter-annual variability in chilling hours and the mean was 170.89 (threshold $7.2^{\circ} \mathrm{C}$ ), also flowering date of 'Picholine' was fluctuating between April 23 to May 7 depending on the season; while the mean GDD for the period from 2008- 2012 was 231.87.

Several studies reported the necessity of chilling for olive flowering, Hartmann and Porlingis (1957) reported no flowering in olive when temperature was higher than $15.5^{\circ} \mathrm{C}$, any way this seems to be cultivar dependent, Malik and Bradford (2006) reported that 'Arbequina' needs lower chilling requirements, while 'Ascolana' needs higher chilling requirements (Kailis and Harris, 2007).

In the present study, 'Picholine' seems to have low chilling requirements, so it could have normal flowering even in relatively warm winters (like 2018 season). This could be in advantage since global warming and increased earth temperature could affect chilling requirements and consequently olive growing negatively. Anyway, calculating the accurate chilling requirements for this cultivar needs further investigation under controlled environment. 
Table 4. Flowering period, Flowering date (FD), Chilling units (CU) and Growing degree days (GDD) for 2017- 2019 seasons in Bouka, Latakia.

\begin{tabular}{|c|c|c|c|c|c|c|}
\hline \multirow{2}{*}{ season } & \multirow{2}{*}{ Flowering period $*$} & \multirow{2}{*}{ FD } & \multicolumn{2}{|c|}{ CU } & \multicolumn{2}{|c|}{ GDD } \\
\cline { 4 - 7 } & & & $\mathbf{7 . 2}^{\circ} \mathbf{C}$ & $\mathbf{1 2 . 5}^{\circ} \mathbf{C}$ & $\mathbf{7 . 2}^{\circ} \mathbf{C}$ & $\mathbf{1 2 . 5}^{\circ} \mathbf{C}$ \\
\hline $\mathbf{2 0 1 7}$ & $(20 / 5)-(3 / 6)$ & 109 & 51.2 & 1284.6 & 842.4 & 226.4 \\
\hline $\mathbf{2 0 1 8}$ & $(12-25) / 5$ & 101 & 0.0 & 326.4 & 1197.4 & 316.2 \\
\hline $\mathbf{2 0 1 9}$ & $(12-27) / 6$ & 116 & 16.6 & 612.0 & 773.1 & 127.3 \\
\hline
\end{tabular}

*flowering period of 2017 season was adapted from (Mhanna et al., 2019).

\section{CONCLUSIONS}

Pistil abortion of olive differed depending on inflorescence position on the flowering shoots, where apical part had the highest pistil abortion ratio; also, season could significantly affect this phenomenon. Significant relationship was found between the number of flowers per inflorescence and the number of flowers with aborted pistils, the significance of this relation could differ depending on inflorescence position on the shoot and season. 'Picholine' seems to have low chilling requirements in Syrian costal area, and flowering parameters showed good adaptability to local conditions. Under global warming conditions, cultivars with lower chilling requirements could have an advantage in areas under threat of climatic change like the Mediterranean area.

\section{REFERENCES}

Aguilera, F., Ruiz, L., Fornaciari, M., Romano, B., Galán, C., Oteros, J., Ben Dhiab, A., Msallem, M., and Orlandi, F. (2014): Heat accumulation period in the Mediterranean region: phonological response of the olive in different climate areas (Spain, Italy and Tunisia). Int J Biometeorol, 58 (5): 867-876.

Alagna, F., Cirilli, M., Galla, G., Carbone, F., Daddiego, L., Facella, P., Lopez, L., Colao, C., Mariotti, R., Cultrera, N., Rossi, M., Barcaccia, G., Baldoni, L., Muleo, R. \& Perrotta, G. (2016): Transcript analysis and regulative events during flower development in olive (Olea europaea L.). PLoS One, 11: e0152943.

Alcalá, A.R., \& Barranco, D. (1992): Prediction of flowering time in olive for the Cordoba Olive Collection. Hortic. Sci. (Prague) 27: 1205-1207.

Aron, R. \& Gat, Z. (1991): Estimating chilling duration from daily temperature extremes and elevation in Israel. Clim. Res., 1: 125-132.

Aybar, V, E., De Melo-Abreu, G.P., Searles, P.S., Matias, A.C., Del Río, C., Caballero, J.M. \& Cecilia Rousseaux, C. (2015): Evaluation of olive flowering at low latitude sites in Argentina using a chilling requirement model. Spanish Journal of Agricultural Research, 13(1): e09-001, 10 pages.

Beyá-Marshall, V. \& Fichet, T. (2017): Effect of crop load on the phenological, vegetative and reproductive behavior of the 'Frantoio' olive tree (Olea europaea L.). Cien. Inv. Agr., 44(1): 43-53. 
Bonofiglio, T., Orlandi, F., Sgromo, C., Romano, B. \& Fornaciari, M. (2008): Influence of temperature and rainfall on timing of olive (Olea europaea) flowering in southern Italy. New Zealand Journal of Crop and Horticultural Science, 36: 59-69.

Garcia-Mozo, H., Orlandi, F., Galan, C., Fornaciari, M., Romano, B., Ruiz, L., Diaz de la Guardia, C., Trigu, M.M. \& Chuine, I. (2009): Olive flowering phenology variation between different cultivars in Spain and Italy: modeling analysis. TheorApplClimatol., 95:385-395.

Ghrisi, N., B. Boulouha, M. Benichou, and S. Hilali. (1999): Agro-physiological evaluation of phenomenon of pollen compatibility in olive. Case of the Mediterranean collection at the Menara station,"Marrakech". Olivae. 79:51-59.

Gupta, R. \& Chakrabarty, S.K. (2013): Gibberellic acid in plant. Still a mystery unresolved. Plant Signaling \&Behavior, 8: 9, e25504.

Haberman, A., Bakhshian, O., Cerezo-Medina, S., Paltiel, J., Adler, C., Ben-Ari, G., Mercado, J.A., Pliego-Alfaro, F., Lavee, S., Samach, A. (2017): A possible role for FT encoding genes in interpreting environmental and internal cues affecting olive (Olea europaea L.) flower induction. Plant Cell Environ. 40: 1263-1280.

Hartmann, H. T., \& Porlingis, I. (1957): Effect of different amounts of winter chilling on fruitfulness of several olive varieties. Bot. Gaz., 119 (2): 102-104.

Kailis, S. and Harris, D. (2007): Producing Table Olives. Landlinks Press, Collingwood, Vic., 328.

Koubouris, G., Limperaki, I., Darioti, M. \& Sergentani, C. (2019): effects of various winter chilling regimes on flowering quality indicators of Greek olive cultivars. Biologia plantarum, 63: 504-510.

Malik, N. \& Bradford, J. (2006): Regulation of flowering in 'Arbequina' olives under non-chilling conditions: The effect of high daytime temperatures on blooming. Journal of Food, Agriculture \& Environment, 4(2): 283-286.

Mhanna, M., Douay, F. \& Rajab, M. (2020): Identifying the Optimal Pollinizer for 'Dermlali' Olive Cultivar under Syrian Coast Conditions. International Journal Of Fruit Science, 20:sup3, S1984-S1993, DOI: 10.1080/15538362.2020.1844112.

Mhanna, M., Douay, F. \& Rajab, M. (2019a): Flower characteristics and sexual compatibility of Italian olive cultivar Coratina under Syrian coast conditions. Agricultural Science and Technology, 11(4): 346-351.

Mhanna, M., Douay, F. \& Rajab, M. (2019b): 'Khoderi' olive cultivar as an efficient polliniser for some French and Italian olive cultivars. Agriculture \& Forestry. 65(4):211-220.

Moreno-Alías, I., De La Rosa, R. \& Rapoport, H. (2013): Floral quality components of a new olive cultivar and its parents. Scientia Horticulturae, 154:17-19.

Ramirez Santa Pau, M., Navarro, C. \& Rallo, L. (2002): Relationship among flowering, fruitfulness and crop in 'Manzanilla de Sevilla' Olives. Acta. Hort., 586: 317-320.

Rapoport, H., Hammami, S., Martins, P., Pérez-Priego, O. \& Orgaz, F. (2012): Influence of water deficits at different times during olive tree inflorescence and flower development. Environmental and Experimental Botany, 77: 227-233.

Rosati, A., Caporali, S. \& Paoletti, A. (2012): Floral biology: implications for fruit characteristics and yield. INTECH., 71-80.

Sanchez-Estrada, A. \& Cuevas, J. (2020): Pollination Strategies to Improve Fruit Set in Orchards of 'Manzanillo' Olive in a Nontraditional Producing Country, Mexico. HortTechnology, 1-7. DOI: 10.21273/HORTTECH04231-18. 
Sanz-Cortés, F., J. Martinez-Calvo, M.L. Badenes, H. Bleiholder, H. Hack, G. Llacer, and U. Meier. (2002): Phonological growth stages of olive trees (Olea europaea). Ann. Appl. Biol. 140:151-157.

Selak, V. G., Goreta Ban, S. \& Perica, S. (2019): Flowering phenology, flower sterility and pollen germination in olive cultivars. Acta Hortic., 1231: 11-16.

Selak, V. G., Goreta Ban, S. \& Perica, S. (2018): Onset of flowering in olive cultivars in relation to temperature. Acta Hortic., 1229: 127- 134.

Zouari, I., Mezghani, A. \& Labidi, F. (2017): Flowering and heat requirements of four olive cultivars grown in the south of Tunisia. Acta Hortic. 1160: 231-236. 